\title{
REINTRODUCTION OF DACTYLORHIZA INCARNATA (L.) SOÓ INTO THE NATURAL HABITATS OF THE EUROPEAN RUSSIA
}

\author{
Shirokov, A. I. - Syrova, V. V. - Kryukov, L. A. ${ }^{*}$-Shtarkman, N. N. - SheStakova, A. A. \\ Botanical garden of the Nizhniy Novgorod State University of N.I.Lobachevsky \\ 23 pr. Gagarina, 603062 Nizhni Novgorod, Russia \\ (phone, fax: +78-314-655-141) \\ *Corresponding author \\ e-mail: lavrkryukov@gmail.com; phone:+79-200-235-327
}

(Received 26 $6^{\text {th }}$ Sep 2016; accepted $1^{\text {st }}$ Dec 2016)

\begin{abstract}
Reintroduction of rare plant species into the natural habitats is one of the important trends of biodiversity conservation. The article presents the results of experiments on the reintroduction into the natural habitat of rare plant species Dactylorhiza incarnata (L.) Soó (Orchidaceae). During the experiment on the reintroduction of the species in 2012 an artificial population was grown in the Nizhny Novgorod region (Russia). According to the results of three years of monitoring, the success of reintroduction was evaluated. The main morphometric parameters, the ontogenetic structure of artificial population and carpological productivity were analyzed. Recommendations for cultivating the artificial populations of Dactylorhiza incarnata in natural habitats were developed.
\end{abstract}

Keywords: orchids, rare species, reproduction in vitro, ontogenetic stages, reintroduction

\section{Introduction}

Orchids is one of the largest families among flowering plants. Specific biological and ecological features, an active impact on the environment and the ruthless harvesting from the nature has led most species of this family to the edge of extinction. As a consequence, many orchids are recognized as endangered and vulnerable species. There are 30 species of orchids growing in the Nizhny Novgorod region (Biryukova et al., 2014), 8 of them are listed in the Red Book of the Russian Federation (Krasnaja kniga, 2005) and 21 in the Red Book of the Nizhny Novgorod region (Krasnaja kniga, 2008). One such species is Dactylorhiza incarnata (L.) Soó, which is also listed as «endangered» in many regional red lists of Central Europe and Scandinavia (GBIF, 2009).

Human impact on habitats of the most plant species causes degradation and impoverishment of vegetation, as a result, the problem of biodiversity conservation and reintroduction of rare and lost species is particularly relevant. Experimental research concerning the reintroduction of rare and endangered species is of great importance as components of a row of measures for the conservation of biological diversity. At the same time, it is very effectively to enrich phytocenoses with the species that need of protection within areas already protected (Gorbunov et al., 2008; Shmaraeva and Ruzaeva, 2009; Guerrant, 2012; Akeroyd and Jackson, 1995; Guerrant, 2013).

The aim of this study is the development and testing techniques of reintroduction and restoration of dying orchid populations on the example of D. incanata in the Pustynsky Reserve the Nizhny Novgorod region (European part of Russia). Under investigation the following targets were faced: 
-Germinating D. incarnata seeds in vitro, cultivation of plants and their preparation for experiments in reintroduction.

-Carrying out experiments on reintroduction of $D$. incarnata into natural habitat.

-Monitoring the transplanted population of D. incarnata.

-Developing recommendations basing on studies on the reintroduction of orchids in natural habitats.

\section{Material and methods}

\section{Study species}

The early-marsh orchid (Dactylorhiza incarnata) is a perennial herb with tubers, dissected by 2-5 (6) of the lobes. Stem is 25-55 (70) cm tall, hollow with diameter of 10 $\mathrm{mm}$ at the base, slightly thickened up to the top, slightly striated, and leafy top to bottom; 4-6 leaves are upward directed, pressed to the stem, narrowly lanceolate without spots. Inflorescence is a dense and many-flowered spike (of 17-74 flowers), 4$12 \mathrm{~cm}$ long and 2. 5-3 cm wide. Bracts are long, lanceolate, pointed, exceeding the flower. Flowers are small, reddish-purple. The outer tepals are oblong-ovate, obtuse with three veins. Two petals of inner whorl are oblique, ovate-lanceolate, obtuse. Labellum has purple-violet pattern of dots and dashes on the top, broadly rhombic, onepiece or three-lobe, obtuse (the length of labellum-4. 2-5. $5 \mathrm{~mm}$, width-5-7 mm). Spur is paler than tepals slightly bent 5-6 mm long and about 1. 5-2 mm thick, slightly longer than the labellum plate. Fruit is a capsule with numerous seeds (Vakhrameeva, 2011). The high degree of species variability is noted by many researchers (Füller, 1972; Averyanov, 1983; Hedrén and Nordström, 2009; Vakhrameeva et al., 2008). There are many varying characteristics: height of the plant, shape, size and color of the leaves, bracts; color of flowers. D. incarnata combines many forms, varieties, ecological types and hybrids.

D. incanata distributed throughout Europe and is characterized as Eurasian (palearctic) species (Flora Europaea, 1980). In Asia, the area encompasses the territory, including Asia Minor, Iran, North Caucasus, Central Asia, Siberia, Mongolia and northwest China. In Russia, it found by the European part of Karelia to the Volga-Don region, the Lower Volga region, east of the Volga and the Pre-Caucasus, Western and Eastern Siberia to Yakutia (Vakhrameeva, 2011). D. incarnata is the species of wet grasslands. It grows mainly in wet and flooded meadows, on the banks of waterbodies, fens and marshs (Schrautzer at al., 2011; Zheleznaya, 2009; Barlybaeva, 2012; Barlybaeva and Ishbirdin, 2013). It may be founded in the forest-steppe regions, in the mountain meadows, coastal dunes, sometimes even in saline soils.

\section{Study area}

Nizhny Novgorod region is located in the central eastern part of the European part of Russia, in the center of the Russian Plain, covering the territory of 76.9 thousand $\mathrm{km}^{2}$. The territory stretches in the meridian direction of more than $400 \mathrm{~km}$, reaching the north $\mathrm{N} 58^{\circ} 06^{\prime}$ the south $\mathrm{N} 54^{\circ} 27^{\prime}$. From west to east the area extends for about $300 \mathrm{~km}$ from the $\mathrm{E} 41^{\circ} 48^{\prime}$ to $\mathrm{E} 47^{\circ} 46^{\prime}$ (Haritonychev, 1978).

The climate of the Nizhny Novgorod region is temperate continental with a warm and short summer, relatively cold winter, the prevailing western transfer of air masses and moderate moisture. According to climatic zoning Nizhny Novgorod region is a part 
of the eastern half of the largest in the Russian Plain climatic region-Atlanticcontinental European temperate climate zone (Trent'ev and Kolkutin, 2004). Nizhny Novgorod region is located in zones of the southern taiga, mixed and broad-leaved forests and forest-steppe. South taiga and subtaiga (mixed) zones encompasses the left side of the Volga River, while broad-leaved forests and forest-steppe covers the right side (Gribova at al., 1980).

The State Natural Biological Reserve "Pustynsky" is located in the north-western part of the Arzamas district of the Nizhny Novgorod region. Its total area is 6200 hectares. The reserve is located on the border of the coniferous-deciduous and broadleaved forests close to the islets of meadow steppes. The territory includes the river floodplains and large lakes. In the reserve there are over 700 species of plants, of the 1 , 200 found in the region. More than 60 species are rare and relict or being at the border of its range (Bakka and Kiseleva, 2009). Coordinates of artificial population of $D$. incarnata are $\mathrm{N} 55^{\circ} 39^{\prime} 56^{\prime \prime} \mathrm{E} 43^{\circ} 35^{\prime} 45^{\prime \prime}$.

There are small populations of $D$. incarnata being found on the territory of the Pustynsky Reserve, the population number varies from 1-3 to 5 individuals and more. Many factors impact on the species population: disperse distribution of individuals and populations, poor resistance to increased competition with neighbor species, excessive grazing and other human activities in the areas of its growing, collection of plants by people.

\section{Methods}

Seeds of $D$. incarnata were sown in the biotechnology laboratory of the Botanical Garden of UNN in vitro. For sowing unripe capsules (seeds inside them are sterile and do not require immediate sterilization) were used. Alcohol is used to sterilize capsules. Sowing was conducted out on sterile medium proposed by Malmgren (Malmgren, 1996), which does not contain inorganic nitrogen and consists of 16 amino acids. After this sowing flasks are kept in the dark in an air-conditioned chamber at $18^{\circ} \mathrm{C}$. After the germination flasks are transferred to a refrigerator $\left(4^{\circ} \mathrm{C}\right)$ for 3 months. Temperature conditions of cultivation alternate every 3 months (cool - cold) to simulate the change of conditions for vegetation. As using up the medium and developing seedlings they are transferred to other culture vessels as well. The duration of cultivation was 1. 5-2 years. As the seedlings develop up to immature stage (that is characterized with developed tubers) plants are transferred into wooden boxes (the size of $40 \times 25 \times 15 \mathrm{~cm}$ ) filled with a mixture of soil, for adaptation and growing. It was made at the end of May-beginning of June (with the onset of summer temperatures being not less than $15^{\circ} \mathrm{C}$ ) immediately after keeping in the refrigerator to stimulate growth processes. The soil substrate used is follows: 1 part crushed pumice (fraction $0.5 \mathrm{~cm}$ ); 1 part of crushed limestone (fraction $0.5 \mathrm{~cm}$ ); 1 part of perlite; 2 parts semi-humificated conifer litter (sifted through a large sieve). Boxes are dig into a seedbed. Seedlings were put into the shade and regular watered. In those conditions the plants had grown for 2 years. Such period is usually enough for plants to grow up to the adult vegetative (virginal) stage. Thus the plants grown are viable to transfer in natural habitats.

Experiments on transferring D. incarnata in the natural habitat were conducted in the territory of Pustynsky Reserve in 2012. Habitats were selected carefully, as well as sites for planting were prepared. In the selected sites seedbeds were made. There were boxes made of planks $1.5 \times 1.5 \times 0.2 \mathrm{~m}$, which dig in the trenches of the same size (their upper edges were placed at ground level). After that, seedbeds were filled with a soil 
substrate consisting of 3 parts of peat, one part of dolomite aggregate (crushed limestone fraction of up to $1 \mathrm{~cm}$ ), 3 parts of the local soil. Then the specimens of $D$. incarnata were transferred in seedbeds. Each plant was separate by not less than 10 and not more than $20 \mathrm{~cm}$ from an adjacent (for higher density to reduce the competitive effect by "weeds"). After transferring, the plants watered. Seedlings were inspected to control and weed every month (3-4 times per the growing season). Next monitoring of artificial populations was carried out. The basic morphometric parameters of plants were measured: the number of leaves, length and width of the leaf blade for vegetative individuals and-the length of the peduncle, the length of inflorescence, the length of bracts, the number of flowers, and the number of formed capsules for generative individuals. Seed production was also calculated. All the values were compared with similar ones in natural populations. Also ontogenetic structure of artificial populations were analyzed. According to periodization of the species ontogenenesis several stages of development are distinguished. Protocorm - the initial stage of seedling. Plantlet (pl) - the stage is characterized by developing the bud with leaf primordiums on top of the protocorm. Juvenile (j) stage is characterized by developing the first green leaf and the first adventitious roots. Immature (im) individuals have 2-3 leaves with veins. The underground part is oblong tuber $0.5-0.7 \mathrm{~cm}$ long, sometimes bifid. Immature stage usually continues 3-4 years. Virginal stage (v) lasts 2-3 years, and is a transitional period to the generative phase of the life cycle. The plant has 3-4 leaves with the length of up to $18 \mathrm{~cm}$ with 10 veins. Tuber is with 3-4 lobes. Generative (g) individuals have 5-6 leaves with the length of $14-17 \mathrm{~cm}$, the number of veins increases to 12 . Tuber has 4-6 lobes of 1-1. $2 \mathrm{~cm}$ long. Generative individuals can be divided into three groupsyoung, middle-aged and old, differing in the number of flowers per stem (Vakhrameeva, 2000). Monitoring artificial populations the ontogenetic status of each individual was determined and ontogenetic spectrum was designed every year.

\section{Results}

Experiment on horticulture cultivation and reintroduction of $D$. incarnata in natural habitats consists of several stages:

-sowing seeds on sterile culture medium in vitro;

-growing seedlings;

-the adaptation and growing the seedlings to adults;

-transferring individuals in natural habitats;

-monitoring of artificial populations and estimation of success of the species reintroduction in the natural habitats.

Seeds of $D$. incarnata germinate well in a culture medium; their germination rate is $60 \%$. When cultivated in vitro, protocorms are able to vegetative propagation under the impact of hormones, as a result the number of cultivated individuals can be significantly increased (Kryukov et al., 2010, 2011). After transferring into containers the adaptation and growing the seedlings to adults were conducted in the Botanical Garden of UNN during 2 years.

Experiments on the reintroduction of the species were started in 2012: 81 individuals were transferred into natural habitats - the survival rate was $100 \%$. All the plants have got acclimatized and were successful in the adult vegetative (virginal) ontogenetic stage. In the second year (2013) 12 species flowered and developed viable seeds. In 
2013, the second site was set up, where another 81 plants were transferred, and the survival rate in the first year was $100 \%$ as well. Thus, in 2013 , the artificial population consisted of 162 plants. The analysis of population trend has shown the death of six individuals at two sites in 2014, and another 36 individuals - in 2015. Thus, the artificial population consists of 120 individuals that are $74 \%$ of the original number. It should be noted that growing next to each other individuals were usually dying. Death can be caused by infection, dry soil, and competition for resources. But there is a possibility that after the first flowering plants have gone into a state of secondary dormancy (Gribova, 1980).

To evaluate the introduction success, the following morphometric parameters are used: for the virginal individuals - the length and width of the leaf blade, for the generative individuals-stem height, inflorescence length, number of flowers per stem, number of developed capsules and number of seeds per capsule. These figures were compared with plants from natural populations (Fig. 1).

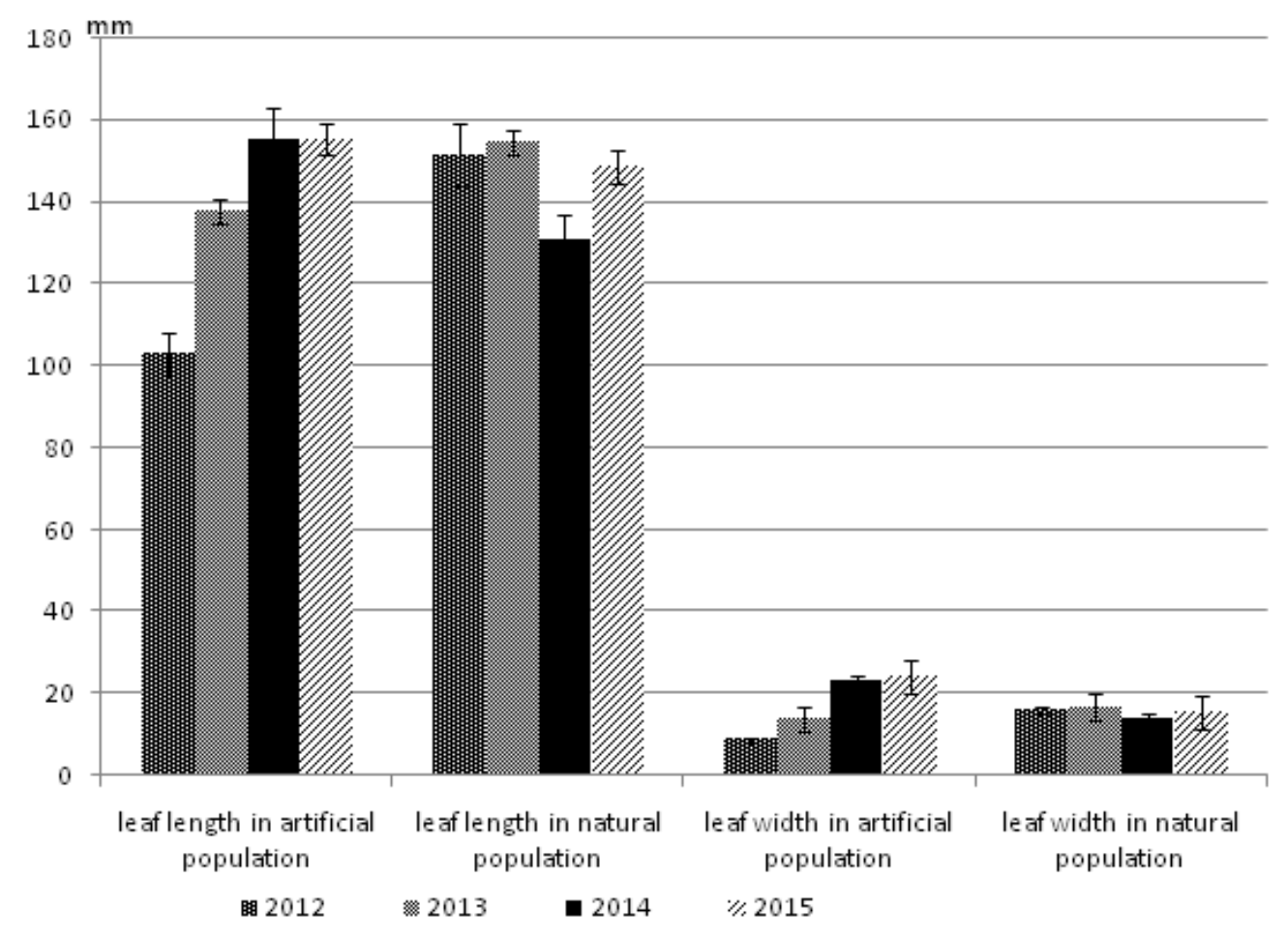

Figure 1. General morphometric parameters (length and width of the leaf) in the artificial and the natural populations for 2012-2015

Data analysis showed the average length of the leaf blade being $102.7 \pm 3.5 \mathrm{~mm}$ and an average width of the leaf blade $-8.8 \pm 0.9 \mathrm{~mm}$ in 2012, 123.1 $\pm 4.2 \mathrm{~mm}$ and 17. $6 \pm 1.4 \mathrm{~mm}$ in 2013 accordingly. In natural populations, those figures were 154. $6 \pm$ 4. $4 \mathrm{~mm}$ and $16.8 \pm 2.5 \mathrm{~mm}$. In 2014 and 2015, the length and width of the leaf of reintroduced individuals exceeded similar parameters of individuals from natural populations (Fig. 1). The data obtained indicate active and successful growth processes of transferred plants. In generative individuals most variational character was the height of generative stem - it varied from 198 to $445 \mathrm{~mm}$, averaging $385.3 \pm 2.5 \mathrm{~mm}$. This 
range of values may indicate the heterogeneity of the artificial population and the successful use of a particular microsite caused by their adaptation to the natural conditions. In natural populations that value was some higher and averaged $583 \pm 1.7$ $\mathrm{mm}$. However, the measured individuals of natural populations could be in the generative old ontogenetic state, whilst the reintroduced individuals were generative young. The same reason can cause a decrease in numbers of flowers in the inflorescences - this value averaged $30 \pm 1.9$ in the artificial population and $57 \pm 1.4$ in natural ones. The number of capsules was also less in artificial populations, averaging $14 \pm 0.9$, than in natural ones $(27 \pm 1.3)$, as well as the number of seeds in capsules: $6775 \pm 147.3$ in the artificial population and $8305 \pm 201$ in natural ones. However the artificial population was recorded fruiting for the first time.

The Table 1 shows the number of flowers and capsules in individuals of the natural population being higher than in the artificial. But it should be kept in mind that the intensity of orchids flowering and fruiting depends largely on age. Comparing these values have been obtained we can confirm the success of flowering individuals of the artificial population. They had flowered the next year after transferring into natural habitats. Five individuals of 12 had more than 30 flowers per stem; the maximum number of flowers was 44 . The average number of fruits was 22. $9 \pm 5.3$.

Table 1. Morphometric characters of studied populations

\begin{tabular}{|l|l|l|}
\hline Characters & $\begin{array}{l}\text { Artificial } \\
\text { population }\end{array}$ & $\begin{array}{l}\text { Natural } \\
\text { population }\end{array}$ \\
\hline Generative stem stature, $\mathrm{M} \pm \mathrm{m}(\mathrm{mm})$ & $385.3 \pm 2.5$ & $583 \pm 1.7$ \\
\hline Length of inflorescence, $\mathrm{M} \pm \mathrm{m}(\mathrm{mm})$ & $115.5 \pm 1.8$ & $130 \pm 2.2$ \\
\hline Length of bracts, $\mathrm{M} \pm \mathrm{m}(\mathrm{mm})$ & $22.6 \pm 0.7$ & $23 \pm 0.3$ \\
\hline Wight of bracts, $\mathrm{M} \pm \mathrm{m}(\mathrm{mm})$ & $5.5 \pm 0.03$ & $4.7 \pm 0.06$ \\
\hline Number of flowers, $\mathrm{M} \pm \mathrm{m}$ (ind.) & $30 \pm 1.9$ & $57 \pm 1.4$ \\
\hline Number of unfertilized flowers, $\mathrm{M} \pm \mathrm{m}$ (ind.) & $8 \pm 1.3$ & $15 \pm 0.9$ \\
\hline
\end{tabular}

According to the analysis of morphometric characters of seeds and their comparison between the artificial and the natural populations it can be said that much of a difference in the size of seeds was not observed. There is a significant difference in the number of seeds per capsule and, as a result, the difference in the seed production. Seed production was 149614. $6 \pm 123.4$ seeds per individual in the artificial population and $348810 \pm$ 257. 2 seeds per individual in the natural one. The share of developed capsules was similar in both populations (73. 6\% for the artificial and $73.7 \%$, for the natural population). The share of full-grown seeds with embryo in the artificial population was $91 \%$ and $89 \%$ in the natural one.

The analysis of fruit and seed production for artificial and natural populations shows the effectiveness of pollination, full development of flowering individuals, high rates of fruit and seed production, high quality of seeds as well. 
The analysis of ontogenetic structure showed the artificial population predominating by virginal individuals against the background of a little number of immature and generative plants in 2013 (Fig. 2).

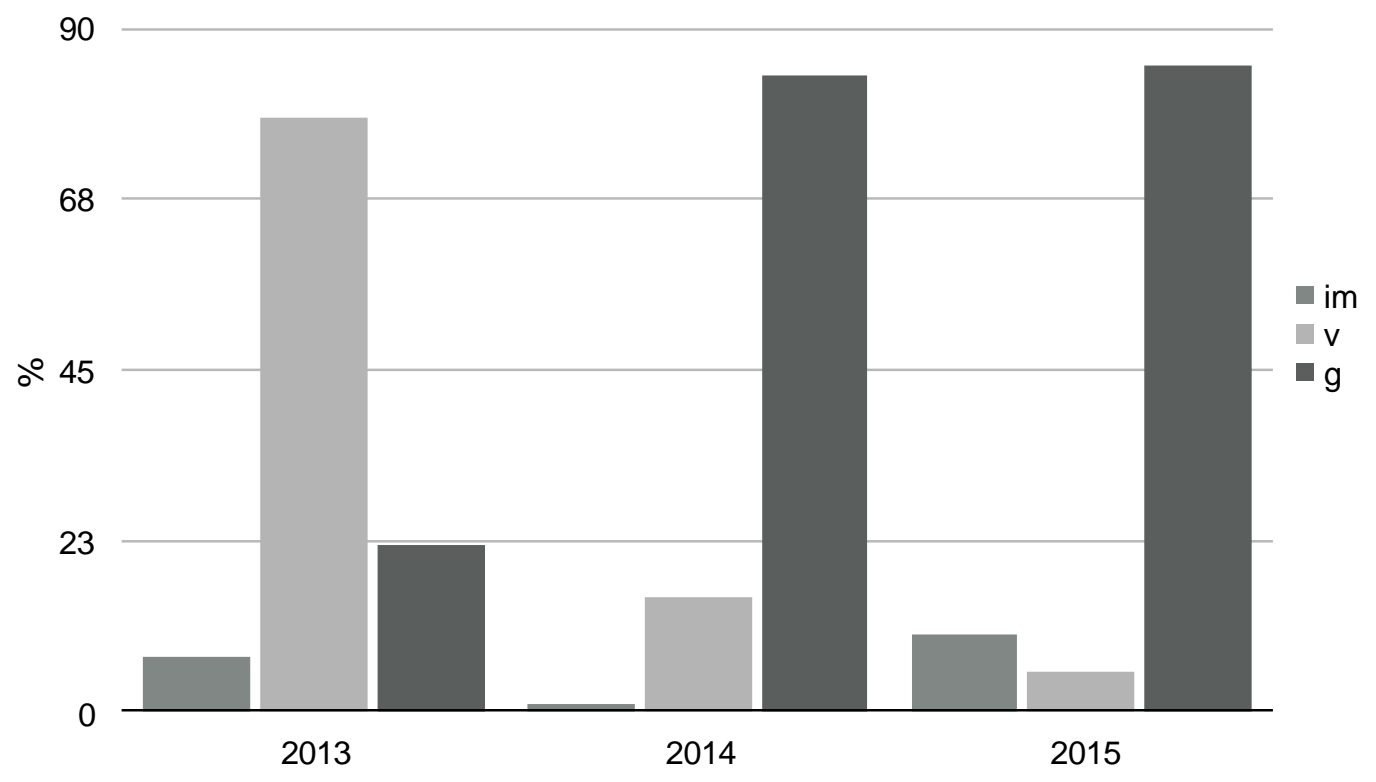

Figure 2. Ontogenetic structure of the artificial population in 2013-2015

In 2014, the structure had changed: the generative individuals began to dominate. In 2015 , the ontogenetic spectrum was also characterized by the predominance of generative individuals and a high percentage of immature plants. The origin of these individuals is unclear. Perhaps they have sprouted from seeds or secondary protocorms, which had developed, when were cultured in vitro, and rested on tubers, or the generative individuals after their first flowering and a period of dormancy have turned into the immature stage. So at the moment, the population has consisted of individuals of different ages and been sustainable.

\section{Discussion}

The criteria for assessing the reintroduction success divides into of the short-term and long-term ones (Valee at al., 2004). The short-term criteria are follows: more than $70 \%$ of transferred plants survive, providing the genetic diversity of the population; the artificial population has similar characteristics to the wild populations; transferred plants survive to reproductive stage, develop flowers and fruits; the level of reproductive yields and seed viability is close to that of wild populations. Long-term criteria: the seedlings developing; the number of individuals within a population stabilizes or increases; an adequate level of biological diversity, particularly genotypic, is preserved, when generations changes (Gorbunov at al., 2008).

We have created an artificial population of $D$. incarnata meets all the short-term criteria of success. The artificial population number in the third year of monitoring was $74 \%$ of the original. The morphometric analysis showed the positive dynamics of growth processes for individuals have transferred for three years. The number of leaves, 
their length and width were increasing. These figures are similar or in some cases higher than the same in natural populations. In the developed population a significant number of individuals became generative (i. e. flowered and fruited) in 2014-2015. According to the published data (Vallius at al., 2007), the success of pollination depends on the number of flowers and density of individuals. In this case, the number of flower was lower than in the natural populations, however the density was higher, which contributed to attract insect pollinators. The number of seeds produced was similar to figures in nature population, while the share of seeds with developed embryo exceeded these figures in natural populations.

In many ways, the reintroduction success is determined by careful selection of the right conditions for the artificial population growing (Sprunger, Prendergast, 2010). D. incarnata like most orchids of moderate cold climate is sensitive to changes in edaphic conditions and characterized by weak competitiveness. Therefore, in addition to the selection of typical habitats for this species (it is optimal if several wild individuals have already been in the site selected) before transferring the sites were carefully preparing.

Concerning the environmental conditions $D$. incarnata belongs to the species of wet meadows and marshes (Vakhrameeva, 2000; Schrautzer at al., 2011; Zheleznaya, 2009; Barlybaeva, Ishbirdin, 2013). In the Pustynsky reserve it distributes in wet and floodplain meadows along the banks of waterbodies, fens and marshes. Therefore, the hydrological regime is one of the species limiting factors. Populations of $D$. incarnata we have found near the Staraya Pustyn village is located are in the meadows, on the territory of the groundwater egress. In such areas the soil is waterlogged and, as a rule, this species grows on the border of the drained and wet areas. Choosing a site for artificial population all these features of the natural habitat of $D$. incarnata were taken into account. As a result, selected site was as close as possible to the actual habitat with waterlogged soil. The site is located in the karst depression with the groundwater egress on the protected area of water well, belonged to the biological station of UNN. The angle of slope is $5^{\circ}$, the exposure is southwest. The dominants of herbage are follows: Scirpus sylvaticus L., Deschampsia caespitosa (L.) Beauv. P., Filipendula ulmaria (L.) Maxim., Equisetum sylvaticum L., Athyrium filix-femina (L.) Roth.

According to the results obtained, we have developed recommendations to horticulture $D$. incarnata under conditions of moderate cold climate:

1. Plants for transferring in the natural habitats should be well developed and healthy. The best results are obtained when plants have been pre-grown for 2 years after their transferring from the nutrient medium. The planting should be carried out in the spring period. For the best pollination and fruit set in the artificial population is advisable to use the seedlings developed from germinated seeds of different populations.

2. Habitats should be selected carefully. D. incarnata grows in wet meadows and marshs often near the groundwater egress. Usually associated species are follows Equisetum sylvaticum L., Scirpus sylvaticus L., Eupatorium cannabinum L., Filipendula ulmaria (L.) Maxim, Geum rivale L. et al. It is desirable that the selected site has been inhabited by single wild individuals of $D$. incarnata (dying population) or at least the species had been registered in that site earlier.

3. To prevent competitive effects on cultivated plants the site should be prepared-a trench width of $60-70 \mathrm{~cm}, 20 \mathrm{~cm}$ deep is made with sides reinforced by planks. The trench is filled with substrate-peat $(50 \%)$ and the local ground, purified 
from plants (50\%), as well as the addition of dolomite aggregate 3.0 liters per $1 \mathrm{~m}^{2}$ of seedbed.

4. The transferred plant is separate by not less than $10-15 \mathrm{~cm}$ from an adjacent. In the process of horticulture it is recommended to loosen the upper layer of the soil and remove weeds carefully. During the dry season (if it is necessary) periodic watering is also recccomended, especially in the first year after planting.

5. To obtain a stable artificial population the seedlings should be planted repeatedly. The annual planting of seedlings should be done at least during 3 years. Thus, in a short period the population consisting of individuals of different ages has developed.

\section{Conclusion}

As a result of this study an artificial population of rare orchid D. incarnata was created in the natural habitat in the territory of the Pustynsky Reserve, which included 162 specimens of plants grown from seeds. Three years later, the population size was 120 individuals. The percentage of survival specimens was $74 \%$.

According to analyzes of seed production and morphometry in the artificial populations of $D$. incarnata the significant variation in values was discovered, but at the same time it indicates a positive trend and successful adaptation of transferred plants in their natural habitat.

The analysis of the ontogenetic structure shows a steady spectrum and predicts a positive trend of the artificial population developing in the future.

To maintain the artificial population further transferring of seedlings and monitoring are needed.

Basing on the study results recommendations for the reintroduction of tuber orchids in natural habitats were developed.

Acknowledgments. We are grateful to Vladimir Vorotnikov, Olga Biryukova, Elena Ganyushkina for consultations.

\section{REFERENCES}

[1] Akeroyd, J. R., Jackson, P. W. (1995): A handbook for botanic gardens on the reintroduction of plants to the wild. - BGCI, UK: 30.

[2] Averyanov, L. V. (1983): Genus Dactylorhiza Nevski (Orhidaceae) in SSSR, Ph. D. Thesis. - St. -Petersburg: 24.

[3] Bakka, S. V., Kiseleva, N. J. (2009): Osobo ohranjaemye prirodnye territorii Nizhegorodskoj oblasti. - N. Novgorod: 560

[4] Barlybaeva, A. A. (2012): D. incarnata (L.) Soó (fam. Orchidaceae Juss.) in the Republic Bashkortostan: ecology and phytosociology. - Izvestija Samarskogo nauchnogo centra Rossijskoj Akademii Nauk 14 1(7): 1701-1702.

[5] Barlybaeva, A. A., Ishbirdin, A. R. (2013): Ecological and phytocenotical characteristics of the D. incarnata (L.) Soo. (fam. Orchidaceae Juss.) habitats. - Izvestija Samarskogo nauchnogo centra Rossijskoj Akademii Nauk 15 3(4): 1219-1222. 
[6] Biryukova, O. V. et al. (2014): The Orchidaceae family in the flora of the Nizhni Novgorod region. - Vestnik of Lobachevsky State University of Nizhni Novgorod 3(3): 16-25.

[7] Flora Europaea (1980). - Cambridge 5: 503.

[8] GBIF (Global Biodiversity Information Facility) (2009). - www. gbif. net.

[9] Global Strategy for Plant Conservation (2002). - BGCI: Richmond, U. K., 13.

[10] Gorbunov, Y. N., et al (2008): Methodological recommendations for botanic gardens on the reintroduction of rare and threatened plants Botanic Gardens. - Conservation International (BGCI): 53.

[11] Gribova, S. A. et al. (1980): Rastitel'nost' Evropejskoj chasti SSSR Nauka: 236.

[12] Guerrant, E. O. Jr. (2012): Characterizing Two Decades of Rare Plant Reintroductions,. Plant Reintroduction in a Changing Climate Promises and Perils 1: 9-29

[13] Guerrant, E. O. Jr. (2013): The Value and Propriety of Reintroduction as a Conservation Tool for Rare Plants. - Environmental Science and Management Faculty Publications and Presentations: 30 .

[14] Haritonychev, A. T. (1978): Priroda Nizhegorodskogo Povolzh'ja: istorija, Ispol'zovanie, ohrana, Gor'kij: 175.

[15] Hedrén, M., Nordström, S. (2009): Polymorphic populations of D. incarnata s. $l$. (Orchidaceae) on the Baltic island of Gotland: morphology, habitat preference and genetic differentiation. - Ann Bot. 104(3): 527-542.

[16] Krasnaja kniga Nizhegorodskoj oblasti (2005) 2. Sosudistye rastenija, vodorosli, lishajniki, griby. N. Novgorod: 328.

[17] Krasnaja kniga Rossijskoj Federacii (Rastenija i griby) (2008). Moscow: 856.

[18] Kryukov, L. A., Shirokov, A. I., Syrova, V. V. (2010): The analysis of vegetative reproductive potential of tuberoid orchids at early development stages. - Vestnik of Lobachevsky State University of Nizhni Novgorod 2(2): 413-417.

[19] Kryukov, L. A., Shirokov, A. I., Syrova, V. V. (2011): Multiplicity of ontogenetic patterns of Dactylorhiza incarnata (L.) Soo in connection with protocorm vegetative propagation in vitro. - Vestnik of Lobachevsky State University of Nizhni Novgorod 6(1): 144-148.

[20] Malmgren S. (1996): Orchid propagation: theory and practice. - Proc. North American Native Terrestrial Orchids "Propagation and Production". Washington: 63-71.

[21] Schrautzer, J. et al (2011): Long-term population dynamics of D. incarnata (L.) Soó after abandonment and re-introduction of mowing. - Flora 206: 622-630.

[22] Shmaraeva, A., Ruzaeva, I. (2009): Reintroduction of threatened plant species in Russia. - BG Journal 6 (1).

[23] Sprunger, S., Prendergast, G. (2010): Experimental introduction of the heath spotted and early marsh orchids into restored ecosystem in Switzerland. - Global Re-introductions Perspective: $332-335$

[24] Trent'ev, A. A., Kolkutin, V. I. (2004): Klimat konca XX veka v srednej polose Nizhegorodskoj oblasti. - Nizhnij Novgorod: 374.

[25] Vakhrameeva, M. G. (2000): D. fuchsii, D. incarnata \& D. maculate. - Biological Flora of Moscow Region 14: 55-86.

[26] Füller, F. (1972): D. und Orchis: 351.

[27] Valee, L. et al (2004): Guidelines for the translocation of threatened plants in Australia. Australian network for Plant Conservation. Australia, Canberra: 80. 
[28] Vallius, E. et al (2007): Reproductive success of D. incarnata ssp. incarnata (Orchidaceae): the effects of population size and plant visibility. - Nordic Journal of Botany 25: 183-189.

[29] Vakhrameeva, M. G. et al (2008): Orchids of Russia and adjacent countries (within the borders of the former USSR). - Ruggell (Liechtenstein): 690.

[30] Zheleznaya, E. L. (2009): Changes in the structure of a D. incarnata (L.) Soó population during the overgrowing of a meadow-bog community complex in the Moscow region. Russian J. of Ecology 40 (1): 39-43. 